\title{
ASSESSMENT AND MODELING THE INFLUENCE OF NITROGEN INPUT IN THE SOIL ON GROUNDWATER NITRATE POLLUTION: PLAIN OF UPPER- CHELIFF (NORTH ALGERIA)
}

\author{
RICHA A. ${ }^{1, *}$ \\ DOUAOUI A. ${ }^{2}$ \\ BETTAHAR N. ${ }^{3}$ \\ QIANG Z. ${ }^{4}$ \\ MAILHOL J-C. ${ }^{5}$
}

\author{
1,* Laboratory Agricultural Production and Sustainable Exploitation \\ of Natural Resource, University of Khemis Miliana, Street Theniet \\ El Had, 44225, Khemis Miliana (Algeria) \\ ${ }^{2}$ University Centre Morsli Abdellah of Tipaza, Laboratory Agricultural \\ Production and Sustainable Exploitation of Natural Resource, \\ University of Khemis Miliana, Street Theniet El Had, \\ 44225, Khemis, Miliana (Algeria) \\ ${ }^{3}$ Laboratory of Water \& Environment Faculty of Civil Engineering and \\ Architecture, Hydraulic department University Hassiba Ben Bouali, \\ BP 151-02000 - Chlef (Algeria) \\ ${ }^{4}$ Institute of Agriculture environment and resources Academy of \\ Agricultural Sciences of the Province of Shan XI, China \\ 5Irstea, The Science and Technology Research Institute for \\ Environment and Agriculture of Montpellier \\ UMR-G-EAU water Management \\ 361 rue J.-F. Breton, BP 5095, 34196 Montpellier, France
}

Received: 03/02/2015

Accepted: $13 / 08 / 2015$

Available online: 20/10/2015 *to whom all correspondence should be addressed e-mail: amricha@yahoo.fr

\section{ABSTRACT}

The present study associates groundwater nitrate pollution with agricultural activity in the Upper-Cheliff wich is known for intensive farming practices. The indicatory kriging method is used in order to elaborate a map of the spatial probability distribution of nitrate concentration that exceeds a threshold value of 50ppm during high watering period for the year 2012. The obtained results show that the areas exceeding nitrate concentrations of $50 \mathrm{ppm}$, occupy more than $80 \%$ of the Upper-Cheliff aquifer area. It appears, from this map, the most affected areas are those for which the level of intensification of the $\mathrm{N}$-fertilizers is the strongest (zone of garden farming, potatoes in particular) throw condensed.These results are coherent with the experimental data, which show an average nitrate concentration value of $75 \mathrm{ppm}$, significantly higher than the World Health Organization (WHO)'S standards.

In this study, the total nitrogen brought to the soils of the Upper-Cheliff is estimated at $247 \mathrm{~kg} \mathrm{ha}^{-1}$ for this year, and compared to the results of New Computer models such as PILOTEN used to analyze alternative management practices together with soil, plant, and climate characteristics to determine the amount of nitrogen leached under the potatoes crops. The result of this model show that $60 \%$ of nitrogen input is leaching under potato crops which is relevant to the map showing the spatial evolution of nitrate. Nitrate pollution in the groundwater of the Upper-Cheliff appears to be significant and driven by the application of both inorganic fertilizer and land use.

Keywords: fertilizers, indicatory kriging, Nleaching, nitrate pollution, modeling, PILOTES, potatoes 


\section{Introduction}

Groundwater nitrate $\left(\mathrm{NO}_{3}{ }^{-}\right)$contamination is increasing rapidly with the ever-increasing massive industrialization, urbanization, and the agricultural expansion with its associated activities that pose high pressure on groundwater resources (Wallis et al., 2011). Previous studies on different aquifers in Algeria (e.g. Kettab, 2005; Hadjouj, 2008) have identified the overuse of nitrogen (N) fertilizer to be one of the main sources for groundwater nitrate. It is often associated with intensive farming. (Bettahar et al., 2009).

In the plain of Upper-Cheliff located in the North of Algeria Algerian where the main activity revolves around agriculture, the nitrate pollution threatens water resources. With a total annual volume of agricultural production around 1.5 million tons, agriculture is certainly the main practice of excellence in the region. Potato, covered nearly half (48\%) of the total agricultural production of Upper-Cheliff and provides more than $40 \%$ of the national production of potato, which is a major consumer of nitrogen fertilizer.

This work aims to visualize the extent of the pollution and to determine its origin and the main mechanisms that govern it. For this, we conducted a measurement campaign in May 2011 on a set of 53 water points (wells and drilling) irregularly distributed, showing the spatial evolution of nitrate through a map established by indicatory kriging method in periods of high waters. A field investigation was carried out in parallel to estimate the total contribution of nitrogen present on soils of the Upper-Cheliff It is supposed to estimate nitrogen brought by $\mathrm{N}$-fertilizers used extensively in garden farming, potatoes in particular.

Due to the complexity of the nitrogen cycle in water-soil-plant systems, the PILOTEN model was selected to calculate the nitrogen balance and simulate $\mathrm{N}$ leaching from a potato cropping.

\section{Materials and Methods}

\subsection{Study area}

The study area is located in the north-west of Algeria. It is bordered to the south by the foothills of the Ouarsenis chain and north by the mountains of Zaccar, east and west.respectivelly by the massives of Gantas and Doui It occupies a territory of $370 \mathrm{~km}^{2}$ approximately in the basin of Cheliff (Fig.1).

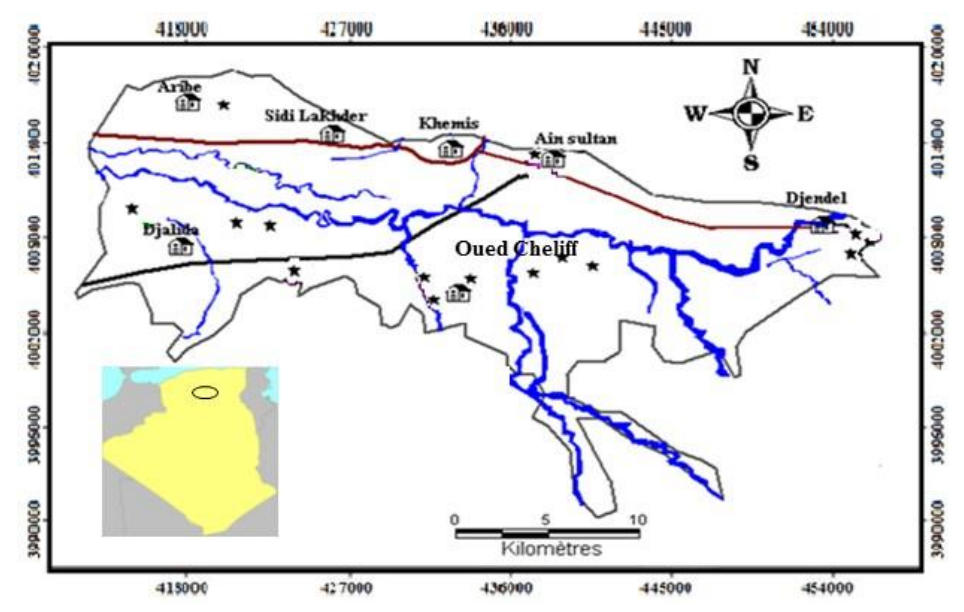

Figure 1. Location map of study area

This area has a typical Mediterranean semi-arid climate with long hot summer and short warm, winter. The considerable difference between the monthly maximum temperature ranging from $\left(46^{\circ} \mathrm{C}\right)$ in July to $\left(0^{\circ} \mathrm{C}\right)$ in January, reflects a marked continental aspect, despite its proximity to the sea because the massive of Zaccar isolates the Upper-Cheliff from the influence of the Mediterranean. 
The water balance established in 2011 (station of Harraza) indicates a relatively high evapo-transpiration and water deficit with $923.38 \mathrm{~mm}$ and $562.58 \mathrm{~mm}$ respectively. The infiltration deduced from the surplus water constitutes $5 \%(25 \mathrm{~mm})$ of total rainfall $(203 \mathrm{~mm})$

\subsection{Hydrogeological context}

Quaternary is an alluvial aquifer forming the embankment of the plain including sand, gravel or clay and sandstone with a maximum depth of $120 \mathrm{~m}$. It is exploited with an annual average volume of approximately $19.4 \mathrm{hm}^{3}(\mathrm{ABH}, 2011)$, It is used for drinking water supply (32\%), irrigation (61\%) and industry (7\%). (Perrodon, 1957; Mattauer, 1958).

In the study area, Lithologic descriptions (ANRH, 2011) indicate that the alluvial sequence is made of gravels and sands with interbedded clay layers of the plain of recent Quaternary. These layers are located in the north and south of the valley with average thicknesses between 8 and $10 \mathrm{~m}$. To the north and west there is a thick clay profile that offers low permeability. Instead, on the edges of the valley, more permeable layers are the unsaturated zone.

The monitoring network with 49 wells and four piezometers enable study of the chemical changes in the water mass and groundwater levels. Water samples were collected in the period from late May to early June, 2011.

The piezometric map established for this period shows closed curves in the center of the plain and open to the edges (Fig.02). Generally, the groundwater flows from east to west. The piezometric level is high in the east of the plain an became weakely to the west. Depressions are observed in the east of the plain due to the effect of intensive pumping for agricultural purposes.

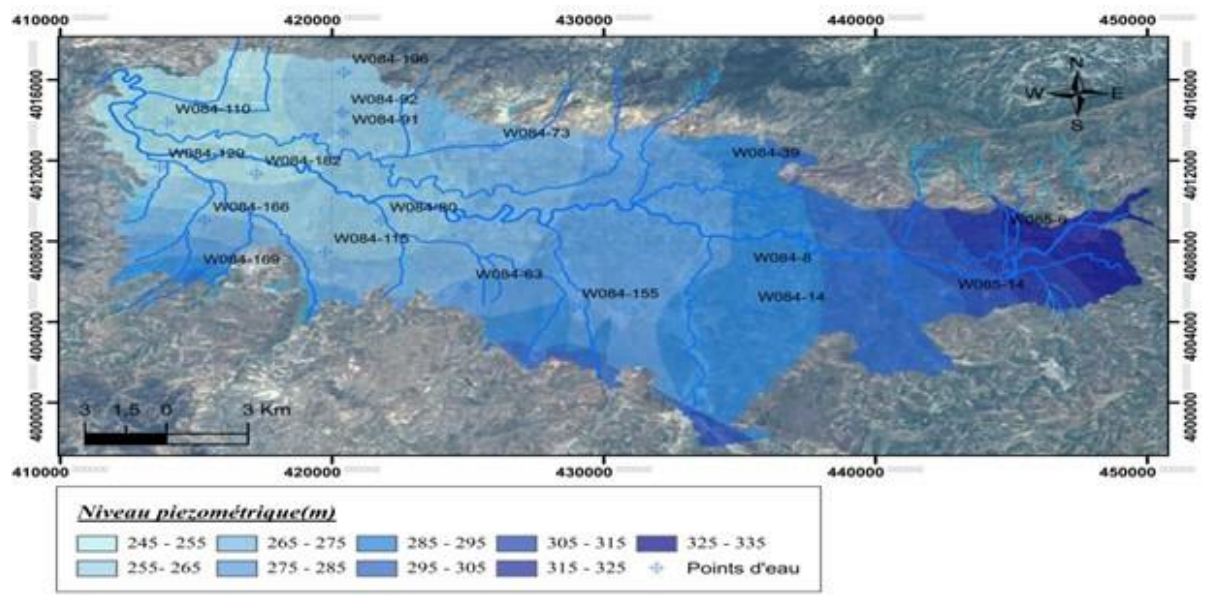

Figure 2. Hydrogeological context of the Upper-Cheliff

In addition to the meteoric water, the aquifer gets a significant piezometric level in the north from the Jurassic limestone manifested by a strong gradient $(0.9 \%)$ in a northeasterly direction. It receives another lower supply from the Cheliff river and tributaries (Deurdeur, Souffay, Boutane ), with a gradient (0.7\%).

\subsection{Soil context}

The soil studies related to the Cheliff Valley which is an alluvial plain with high agricultural potential are numerous (Boulaine, 1957b; Daoud, 1993), soils often have a structure of average to poor stability (Haddaj, 1970; Derdourn, 1983).

These soils are poorly differentiated, more or less calcareous with variable textures, sometimes with local hydromorphism aspects, also the presence of vertic soils. (Boulaine, 1956; Daoud, 1993).

There are two big classes of soils:

- piedmont Soils only observed on the borders of the valley, with a balanced texture $(40 \%$ sand, $35 \%$ silt, $25 \%$ clay), well structured and having therefore a very good permeability. The high 
permeability of these soils results in the quick transport of water infiltration into the deeper layers. The dwelling time of water in the surface layers is very short, so that nitrates are leached faster than the speed of biological processes.

- Soils of the plain (alluvial) have generally locally variable clay texture. Heavy soils ( $\geq 40 \%$ clay on average) are important in the most recent alluvial formations such as plain Djellida and the left bank of the plain of El Khemis they may show signs of water logging and salinity (conductivity between 2 and $72 \mathrm{dS} \mathrm{m}^{-1}$ ) related to a local deficient internal drainage, causing the decline in already low permeability.

Table 1. Soil characteristics (surface horizon: $0--30 \mathrm{~cm}$ )

\begin{tabular}{cccccccc}
\hline & pH & C.E (dS m $\left.\mathbf{~}^{-1}\right)$ & $\begin{array}{c}\mathrm{CaCO}_{3} \\
(\%)\end{array}$ & $\begin{array}{c}\text { Organic matter } \\
(\%)\end{array}$ & $\begin{array}{c}\text { Clay } \\
(\%)\end{array}$ & $\begin{array}{c}\text { Silt } \\
\text { (\%) }\end{array}$ & $\begin{array}{c}\text { Sand (grittiness) } \\
\text { (\%) }\end{array}$ \\
\hline $\begin{array}{c}\text { 0-30 cm } \\
\text { Soil layer }\end{array}$ & 7,7 & 1,4 & 3,17 & 2,3 & 32 & 43 & 25 \\
\hline
\end{tabular}

\subsection{Land Use}

The information collected from the department of the agricultural services of Ain Defla reports that $18 \%$ of the agricultural land areas are actually irrigated. Garden farming is the most profitable, concentrated throughout the valley and especially in the west side. Wells and drillings (boreholes) in the area and releases from dams Ghrib, Deurdeur and Harraza are used for irrigation. The annual average concentrations of nitrates in the waters of the dams are low $\left(<20 \mathrm{mg} \mathrm{l}^{-1}\right)$ (ANRH, 2011) and can act as diluents.

Covering a total area of 5636 ha, garden farming is the main culture in the Upper Cheliff (Fig. 3) and is located mainly near the edges of the valley (the Aribs, Djendel Sidi lakhder, Djelida), their irrigation is provided by individual wells (ONID, 2012).

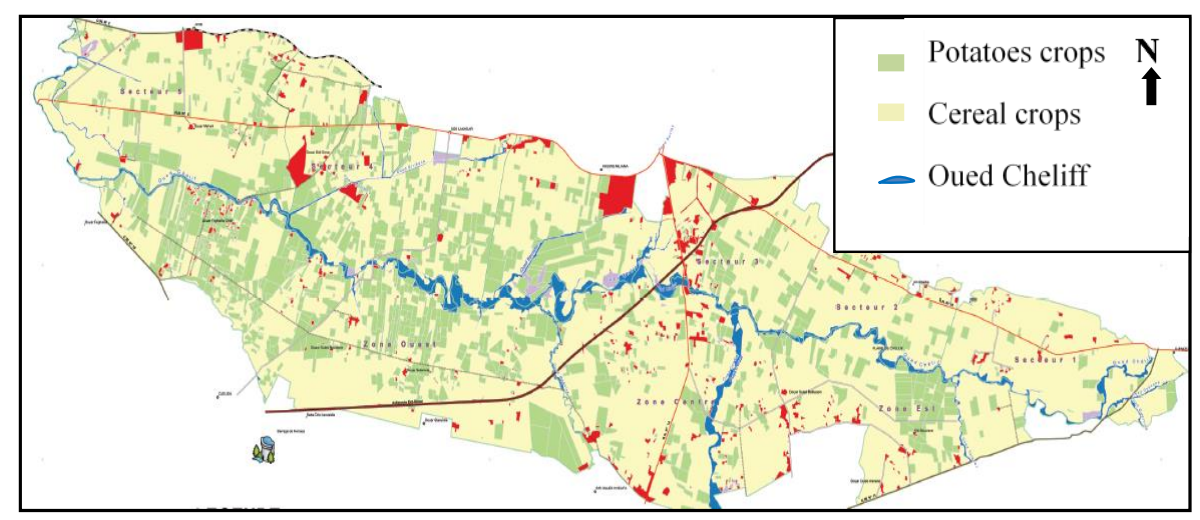

Figure 3. Plan of the land use in the Upper-Cheliff plain

\subsection{Sampling and analytical methods}

A total of 53 groundwater samples irregularly distributed in the area were collected from shallow wells (mostly <120 m deep) during campaigns carried out in May 2011 .

A piezometric campaign and chemical analysis were carried out after application of large amounts of nitrogen fertilizer, especially fertilizers used extensively in garden farming. Water depths in the wells ranged from 4 to $40 \mathrm{~m}$ with an average oscillating around $18 \mathrm{~m}$.

Samples of water filtered at 0.45 microns using syringe filters (Sartorius) are taken in Stoppard plastic (polyethylene), previously rinsed with filtered water sample, and immediately stored to keep temperature below at $4^{\circ} \mathrm{C}$ until arrival at the laboratory. 
In the laboratory, they are placed in the refrigerator and analyzed within 24 hours of collection. The physico-chemical parameters ( $\mathrm{T}, \mathrm{pH}$, conductivity) were in situ measured using a multi-parameter WTW Universal Conductivity Meter Multi-Line P4 set and probes.

The analysis of chemical elements was performed by the following methods (Rodier, 1996): the calcium, hardness (TH), magnesium, chloride and bicarbonate by titration, sodium and potassium were determined by the spectrophotometer flame emission (brand JENWAY PFPZ) on the wavelengths of 589 and $766.5 \mathrm{~mm}$ in. Sulfates and nitrates were determined by a spectrophotometer HACH DR/4000 brand, model 48000) on the wavelengths 420 and $415 \mathrm{~nm}$, the estimated absolute error of the various chemical and physico-chemical parameters are identified in Table II. According to different analyses the ionic balance is less than $5 \%$.

The ordinary and indicator kriging with semi-variogram modeling implemented in the geostatistical analyst of the ArcGIS9.3 package was then used to produce spatial maps of the measured and estimated spatial evolution of nitrate in groundwater.

For modeling the effects of potato crop agricultural practices on nitrate leaching in groundwater, we selected the PILOTEN model.

\subsection{Spatial prediction of Nitrate (Geostatistical modeling)}

The characterization of groundwater quality by geostatistical methods has been achieved in problems related to the simulation of the hydrogeological spatial variables (Delhomme, 1978; Goovaerts et al., 2005; Stigter et al., 2006), which estimate and characterize groundwater quality (Adhikary et al., 2010; Antunes and Albuquerque, 2013; Baalousha, 2010; Dash et al., 2010; Lee et al., 2008; Liu et al., 2004; Mendes and Ribeiro,2010; Mario et al., 2014)

The indicator kriging helps in mapping the probabilities of different threshold levels for retained nitrate and the average probability of nitrates by calculating their mathematical expectation.

The indicator kriging is a nonparametric method based on a prior transformation of the studied variable indicator taking the value 0 and 1 according to the variable thresholds chosen (Bierkens and Burrough, 1993; Douaoui, 2005). Spatial analysis of this method of kriging is not done with the variable itself, but on the transformed variable by binary coding called indicator function. The threshold values depend, in our case, on the limits of nuisance or toxicity (drinking water standards).

The calculation of the indicator variogram functions of the given threshold determines the spatial structure.

$$
V^{*}(h, c)=\frac{1}{2 N}(h) \sum_{i=1}^{N(h)}\left[\left(x_{i}, c\right)-I\left(x_{i}+h \pm \Delta h, c\right)\right]^{2}
$$

Where: $N(h)$ is the number of pairs of remote observations of $h \pm \Delta h$

Ordinary Kriging at a point $\left(\mathrm{x}_{0}\right)$ of $\mathrm{I}(\mathrm{xi}, \mathrm{c})$ is done according to the equation:

$$
I^{*}\left(x_{0}, c\right)=\sum_{i=1}^{n} \lambda_{i} l\left(x_{i}, c\right)
$$

$\mathrm{n}$ : the number of data points included in the estimate

$\lambda_{\mathrm{i}}$ : the weight assigned to the experimental points

The difference between the estimates of indicator functions for two consecutive threshold values is used to calculate the corresponding probability at any point:

Probability $(X=c)=$ Probability $\left(X \geq Z_{c}\right)$ - Probability $\left(X \geq Z_{c+1}\right)$

$Z_{c}$ and $Z_{c+1}$ are the two threshold values

The mathematical expectation is calculated according to the different used probabilities: 
$E(Z)=Z_{c}+2 Z_{c+1}+3 Z_{c+2}+\ldots \ldots$

\subsection{PILOTEN Modeling}

PILOTEN model was selected for simulating the effects of agricultural practices on nitrate leaching, in the Upper-Cheliff. PILOTEN is a model developed by Irstea whose principles are specified in particular in Articles of Mailhol et al.(1997); Khaledian et al.(2009).

It requires daily weather data: Rainfalls, initial evapotranspiration (ETO), global radiation and mean temperature. It also requires information on the plant (planting date, root growth, physiological status) and soil (initial water reserve, volumetric water content at field capacity and wilting point)

Associated with climate data (rainfall, average temperature, evapotranspiration, global radiation) the period over which the simulation is done, the combination of two modules provides for a crop and soil characteristics data, an estimate of yield and water consumption required to achieve this performance (inputs other than irrigation are assumed to be non limiting).

The calibrated and validated PILOTEN model was applied to field experiments in a Mediterranean area (Morocco, Spain, France) where potato cropping systems under common local agricultural management practices were implemented.

PILOTEN performs a complete nitrogen balance in a simulation period. (Mailhol et al., 2011) The software also evaluates the $\mathrm{N}$ draining and $\mathrm{N}$ leaching. It is a well-known code that has been used to estimate the leaching of nitrogen.

\section{Results and Discussion}

\subsection{Nitrate mapping}

Two threshold values were used: the first corresponds to greater than $50 \mathrm{mg} \mathrm{l}^{-1}$ which is the maximum limit set by the WHO levels: the second value equals to $80 \mathrm{mg} \mathrm{l}^{-1}$. It is chosen taking into account the distribution of data and a limit beyond which the water consumption is very dangerous.

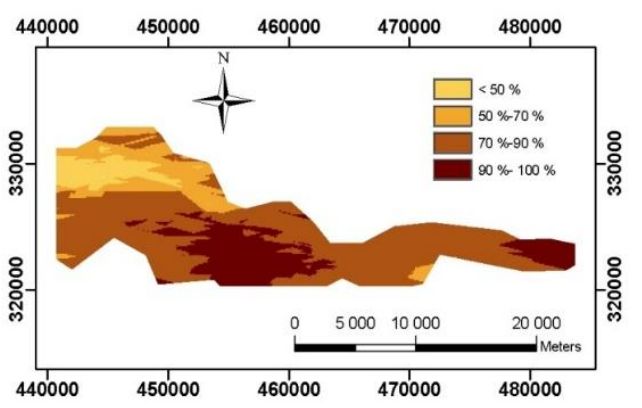

(a)

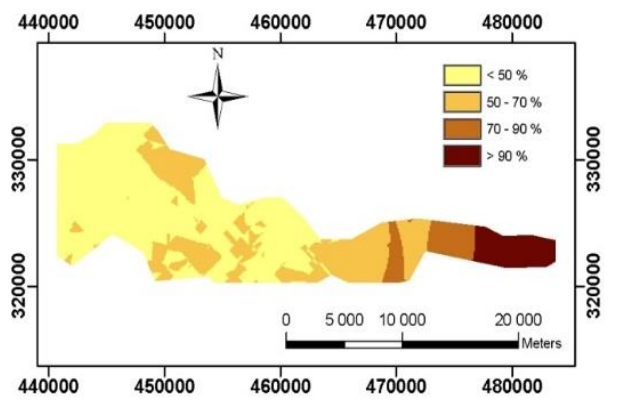

(b)

Figure 4. Maps of the probabilities estimated by indicator kriging thresholds $50 \mathrm{mg} . \mathrm{I}^{-1}(\mathrm{a})$ and $80 \mathrm{mg} . \mathrm{I}^{-1}(\mathrm{~b})$

The average variogram (omnidirectional) calculated for the mathematical expectation of nitrate shows a good spatial structure with a range equal to $11900 \mathrm{~m}$. The latter expresses that good spatial continuity and also shows a pattern in the spatial variability of nitrates in view of the high ratio between the address which is equal to $0.26\left(\mathrm{mg} \mathrm{l}^{-1}\right)^{2}$ and the nugget effect equal to $0.04\left(\mathrm{mg} \mathrm{l}^{-1}\right)^{2}$ (fig.7).

The indicator kriging was used to model the spatial variability of nitrate pollution in ground-water of the Upper-Cheliff. The map established by Indicator Kriging (IK) method Map of the mathematical expectation of nitrate is established to map (Fig.7). It appears from this map that the most affected zones 
$\left(\mathrm{NO}_{3}>65 \mathrm{mg} \mathrm{l}^{-1}\right)$ are those for which the level of intensification of the $\mathrm{N}$-fertilization (zones of garden farming) are the strongest (Bettahar et al., 2009).

It is in the east of the plain where the old alluvial soils and non-clayly foothills are characterized by the highest permeabilities (Xu et al., 2013). The sensitivity of the soil to nitrate leaching is therefore very high. In these same areas, the exploitation of the breeding is more intensive.
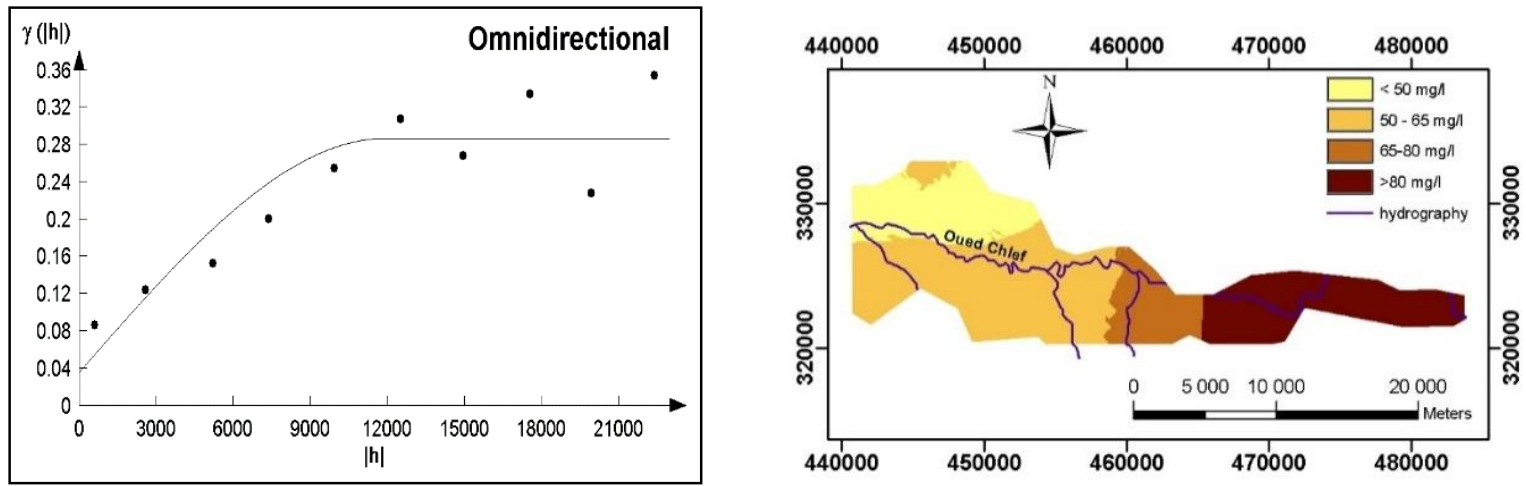

Figure 5. Variogram and Map of nitrate concentrations estimated by indicator kriging

As to the southwest extension, it contains a high nitrate levels $\left(\mathrm{NO}_{3}>50 \mathrm{mg} \mathrm{l}^{-1}\right)$ despite the very fine texture of the soil, due to the accumulation of pollution in the direction of water flow from upstream to downstream. With the exception of a zone located in the extreme north, the weak values of nitrate concentration are located in the northwest of the plain and do not exceed $50 \mathrm{mg} \mathrm{l}^{-1}$. In this area, fine texture of the soil reduces significantly the spread of nitrates in depth due to the low permeability (Cheloufi \& Jacquin, 2000).

\subsection{Quantification of total nitrogen inputs in the study area}

The estimate of the total nitrogen input can be given by the following equation:

\section{$\Sigma$ ENTRIES $=$ Natural Contributions + non natural contributions}

With

Natural contributions $=$ Atmospheric nitrogen contributions + Contributions by mineralization

Non natural contributions $=\mathrm{N}$-fertilizers + water of irrigation + breeding + municipal wastewater

The nitrogenous balance method suggested by the COMIFER (1996) and the CORPEN (1988), permits the nitrogenous excess calculation.

In this work we are interested in calculating the nitrogen input from the non natural sources. During the year 2011, they are estimated at $5633 \mathrm{t} \mathrm{year}^{-1}$ brought on the soils of the Upper-Cheliff plain. Nitrogen brought by agriculture (fertilizers and irrigation) equals to $62 \%$ of the total nitrogen applied to the soils of the region. $90 \%$ of the latter is attributed to nitrogen fertilizer intensively used in garden farming, potatoes in particular. Extrapolated to the total irrigated area, this contribution (related to fertilizers) was estimated at $247 \mathrm{~kg} \mathrm{ha}^{-1}$ for this year.

\subsection{Contribution from fertilizers}

A field investigation from 350 agricultural exploitations has allowed us to develop a calendar of cultural practices (dates, fertilization) and estimate, therefore, nitrogen inputs for each type of land use (Table II). The industrial chemical fertilizers, especially, 15.15.15 NPK are predominating in almost all of the exploitations with annual average doses of $2000 \mathrm{~kg} \mathrm{ha}^{-1}$ for potato, used as background fertilizer. Other fertilizers such as urea (46\%) are used as cover fertilizer. The amount of nitrogen obtained for each crop type is deducted from the product of the fertilizer dose with the corresponding area of application. 
Table 2. Results of the investigation into the agricultural practices in the Upper-Cheliff

\begin{tabular}{|c|c|c|c|c|c|c|c|c|c|c|c|c|}
\hline & $\mathrm{J}$ & $\mathrm{F}$ & $\mathrm{M}$ & $\mathrm{A}$ & $\mathrm{M}$ & $\mathrm{J}$ & $\mathrm{J}$ & A & $\mathrm{S}$ & 0 & $\mathrm{~N}$ & $\mathrm{D}$ \\
\hline \multicolumn{13}{|l|}{ Arboriculture } \\
\hline \multicolumn{13}{|l|}{ Potato crops } \\
\hline \multicolumn{13}{|l|}{ Cereals } \\
\hline & & & & & & $\begin{array}{l}\mathrm{K} 1 \\
\%, 2\end{array}$ & $\begin{array}{l}\text { 5.15) } \\
\text { sulfa }\end{array}$ & & & & & \\
\hline
\end{tabular}

\subsection{Contribution from the water of irrigation}

Garden farming and cereals surfaces are irrigated from groundwater of which nitrate concentrations, for the majority, exceed the critical value for drinking water set by World Health Organization $\left(50 \mathrm{mg} \mathrm{I}^{-1}\right)$ (Bettahar \& Douaoui, 2007). Referring to the potability standard $\left(50 \mathrm{mg} \mathrm{l}^{-1}\right)$, we can estimate the amount of nitrogen in this water using the formula below: (Martin, 2003; Bettahar, 2012)

$$
\mathrm{x}_{\mathrm{n}}=\frac{\left[\mathrm{NO}_{3}^{-}\right] \times \text {Qirrig }}{4,43 \times 10^{2}}
$$

$\mathrm{X}_{\mathrm{N}}$ is the annual amount of nitrogen applied by irrigation water $\left(\mathrm{kg} \mathrm{N} \mathrm{ha}^{-1} \mathrm{an}^{-1}\right),\left[\mathrm{NO}^{-3}\right]$ is the concentration of nitrate in well water $\left(\mathrm{mg} \mathrm{l}^{-1}\right)$ Qirrig and the annual amount of irrigation water $\left(\mathrm{mm} \mathrm{an}^{-1}\right)$. The 4.43 figure is the ratio of molar masses $\mathrm{NO}_{3} \mathrm{~N}^{-1}$.

The total quantity of nitrogen brought by the water of irrigation in the year 2011 was 344.58 t year $^{-1}$ (Fig.6) which represents only $10 \%$ of the one produced by the nitrogen fertilizers $\left(3139.65 \mathrm{t} \mathrm{year}^{-1}\right)$.

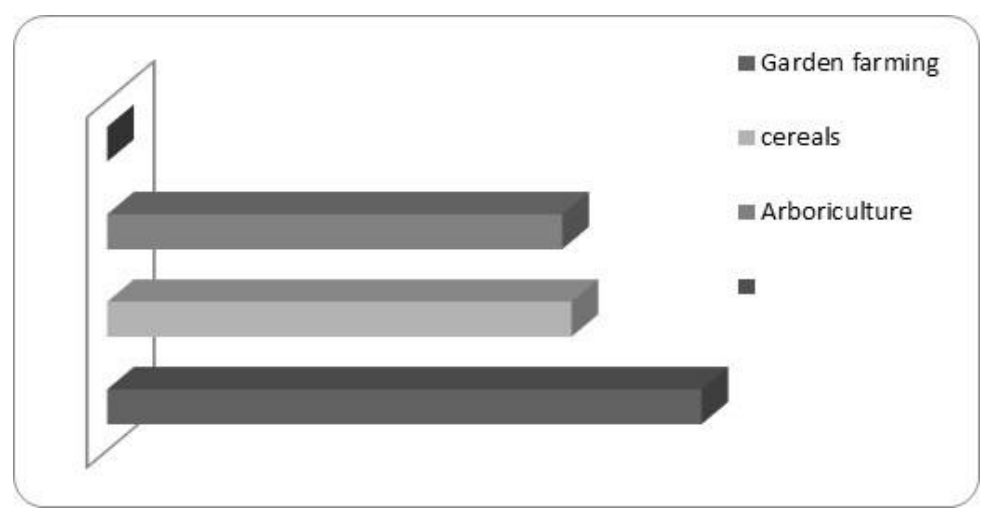

Figure 6. Results of the investigation into the agricultural practices in the Upper-Cheliff

\subsection{Contribution from breeding}

The calculation of the yearly total quantities of organic nitrogen generated by the set of each animal category for the year 2011 is based on the values of nitrogen produced annually per head for each species proposed by the (CORPEN 1988, 1999 and 2001). The results that we obtained show that the majority of this organic nitrogen is produced by cows $\left(1515.7\right.$ t year $\left.^{-1}\right)$.

\subsection{Domestic and industrial inputs}

Organic nitrogen estimated for Individual septic tank systems constitutes only $23 \%$ of the one generated by the breeding.

The estimate of the yearly total quantities of organic nitrogen produced by domestic sewage is based on the nitrogen content of the volume of domestic wastewater produced by populations not connected to the sewage network.. 
The nitrogen produced by nitrogen fertilizers is estimated to $56 \%$ of the total nitrogen input added to the soil of the plain of the Upper-Cheliff for 2011.The contribution from breeding and domestic wastewater assessed represents about $38 \%$ of the total nitrogen (5633.13 t) brought on the soils of the plain of the Upper-Cheliff during that year.

The dumps, often seen on permeable soils, can also convey important quantities of nitrates in depth that is difficult to quantify at this stage of study.

\subsection{Modeling results of $N$ leaching under potato crops}

Simulated amounts of infiltrated water and $\mathrm{N}$ leached past $0.9 \mathrm{~m}$ depth for each potato crop period are shown in graphs. As encountered by other authors (Doltra and Muñoz, 2010), the days when $\mathrm{N}$ leaching occurs correspond to the days of heavy rains or irrigation period (Table 3 ).
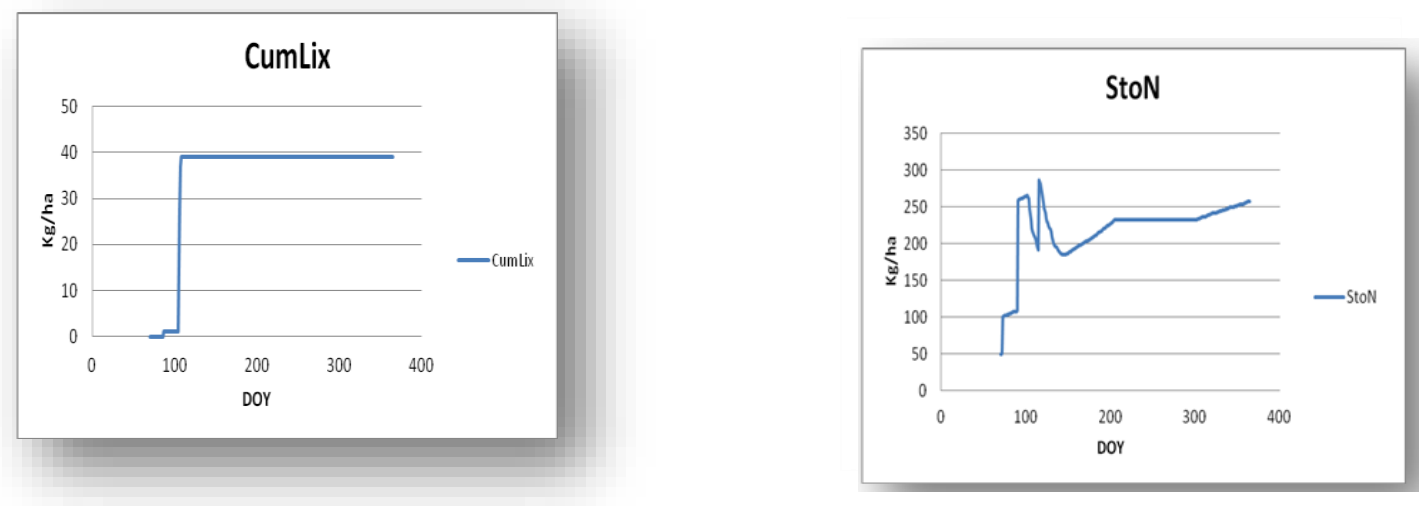

Figure 7. Cumulative nitrogen leached and cumulative nitrogen stock in the soil
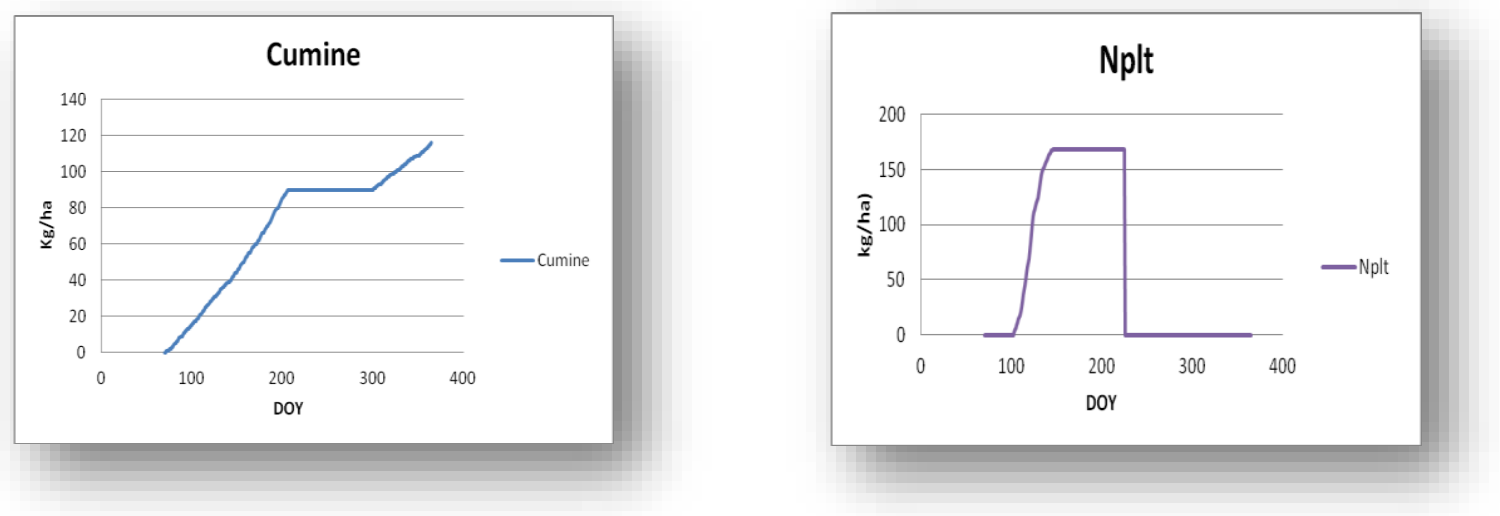

Figure 8. Cumulative nitrogen mineralization and cumulative nitrogen absorbed by theplant

With regard to nitrate leaching, the main difference between rainfall and the application of irrigation water is the nitrate concentration it holds. The average nitrate concentration in rainwater over the whole studied period was in the order of $6 \mathrm{mg} \mathrm{l}^{-1}$, whilst in irrigation water pumped from the Mio-Plioquaternary aquifer the nitrate concentration oscillated between 80 and $300 \mathrm{mg} \mathrm{I}^{-1}$. Irrigation water alone accounted for an input of $344 \mathrm{t} \mathrm{year}^{-1}$ for the 2011.

The period of leaching $\mathrm{N}$ coincides with fertilizer applications and irrigation groundwater. Over this period there was a $134 \mathrm{~mm}$ increase in drained water, which transported $143 \mathrm{~kg} \mathrm{~N} \mathrm{ha}^{-1}$. The total $\mathrm{N}$ leached for the 2011 crops was $148 \mathrm{~kg} \mathrm{~N} \mathrm{ha}^{-1}$ (Table III).

This implies that the intensification of fertilizer and irrigation frequent applications played an important role in the total $\mathrm{N}$ leached increasing, especially under potatoes crops. 
Table 3. Simulation results of the nitrogen balance established by PILOTEN

\begin{tabular}{ccccccc}
\hline $\begin{array}{c}\text { Total rain } \\
(\mathbf{m m})\end{array}$ & $\begin{array}{c}\text { Evaporation } \\
\text { soil }\end{array}$ & Drainage & $\begin{array}{c}\mathbf{N} \text { lessives } \\
\mathbf{k g ~ h a}^{-1}\end{array}$ & $\begin{array}{c}\text { Mineralization } \\
\mathbf{k g ~ h a}^{-1}\end{array}$ & $\begin{array}{c}\text { Denitrification } \\
\mathbf{k g ~ h a}^{-1}\end{array}$ & $\begin{array}{c}\text { Stock Final } \\
\mathbf{N} \text { soil } \mathbf{~ k g} \\
\mathbf{~ h a}^{-1}\end{array}$ \\
\hline 336 & 341 & 134 & 148 & 234 & 0 & 568 \\
\hline
\end{tabular}

The nitrogen produced by fertilizers is estimated at about $56 \%\left(154 \mathrm{~kg} \mathrm{~N} \mathrm{ha}^{-1}\right)$ of the total nitrogen input added to the soil of the plain of the Upper-Cheliff for 2011. The model of simulation has shown that $95 \%$ of $\mathrm{N}$ lixiviation was from the potatoes crops.

This lixiviation under the potato crops coincides with the same zone of high nitrate concentrations $\left(\mathrm{NO}_{3}>50 \mathrm{mg} \mathrm{l}^{-1}\right)$ located to the map of nitrate established by indicator kriging.

With this final stock of $\mathrm{N}$, we tried to make a simulation of nitrgen balance for wheat crops planted just after potao.

In this scenario it would be interesting to grow wheat just after potato without nitrogen brought, it consume the available nitrogen in the soil, which could be from this model reduced the amount of $\mathrm{N}$ leached $0 \mathrm{~kg} \mathrm{~h}^{-1}$.

\section{Conclusions}

The spatial relationship between $\mathrm{NO}_{3}{ }^{-}$concentrations in well waters and the $\mathrm{N}$ leaching under potato crops were studied in the Upper-Cheliff plain. Nitrate pollution in aquifers of the Upper-Cheliff in semiarid climate. appears, important, with high levels of nitrogen (5500 T), brought annually to the soils of Upper-Cheliff by different practices (agriculture, breeding), don't reach the aquifer because of the climate and the soil characteristics. We also found that the indicator kriging method, correctly reflects the potential risk of nitrate pollution exceeding the maximum allowable value for drinking water, and is a suitable tool for the assessment of uncertainty in local estimation. From the results, the standard error maps portrayed the suitable reliability of the prediction map, although extra sampling points are suggested for monitoring, especially near the boundaries to reduce the estimation error in a non-sampled region.

It has also been shown that land use plays an important role on the water quality change, such as potato corps, where we found high nitrate concentration. Therefore, integrated aquifer management strategies can be designed, when water quality analyses are complimented with land use. PILOTEN was able to predict water content at different depths and nitrate concentration in drained water past $0.9 \mathrm{~m}$ depth with reasonable accuracy providing good predictions compared to field observations. This model simulates the amount of water drained and $\mathrm{N}$ leached below the root zone. Also, the adopted approach of comparing total nitrogen input content in soil of Upper-Cheliff to the $\mathrm{N}$ leaching under potato crops (the main culture in the region) and simulated data at $0.9 \mathrm{~m}$ depth with reasonable accuracy providing good predictions compared to field observations. The model simulated the amount of water drained and $\mathrm{N}$ leached below the root zone. This extra $\mathrm{N}$ input to the system from irrigation water should be considered in the $\mathrm{N}$ budget when designing fertilizer applications following crop requirements. Planned measures to reduce the impact of fertilizers and irrigation on the aquifer need to be taken by the agricultural and water sectors. However, these options should rely on technical and socioeconomic requirements.

\section{References}

ABH-CZ.(2004), Hydraulic Cadastre, Mission I. Basin Agency Cheliff -Zahrez (in French), Algeria. p. 80.

Achour F.(1997), Hydrological and water availability conditions in semiarid region: Application of new methodologies in the Cheliff Basin, Algeria. Ph.D. Dissertation (in French), University of French -Comté, France. p. 261. 
Adhikary P.P., Chandrasekharan H., Chakraborty D. and Kamble K. (2010), Assessment of groundwater pollution in West Delhi, India using geostatistical approach, Environ Monit Assess, 167, 599-615.

ANRH. (2004), Hydrogeological Yearbook of alluvial aquifer of high and medium Cheliff (in French). National Agency of Water Resources, Algeria. p. 13.

ANRH.(1993), Pollution by nitrates. National Agency of Water Resources (in French), Algeria.p.15.

Antunes I.M.H.R. and Albuquerque M.T.D. (2013), Using indicator kriging for the evaluation of arsenic potential contamination in an abandoned mining area (Portugal), Sci Total Environ, 442, 545-552.

Baalousha H.(2010), Assessment of a groundwater quality monitoring network using vulnerability mapping and geostatistics: a case study from Heretaunga Plains, New Zealand, Agric Water Manage, 97, 240-246.

Barton L., McLay C.D., Schipper L.A. and Smith C.T. (1999), Annual denitrification rates in agricultural and forest soils, Rev Australian Journal of Soil Research, 37, 1073-1093.

Bettahar N. and Douaoui A. (2001), Spatial evolution of the hardness of the water in the plains of Cheliff. Using the geostatistical approach, Bull Ass Geogr Feeder Territ., 9, 115--121.

Bettahar N. and Douaoui A. (2007), Effect of the pedoclimatic conditions are nitrogen assessment, Arab Water World - AWW, XXXI, 8, 41--42.

Bettahar N.(2012), Effect of the Climate and Soil Characteristics on the Nitrogen Balance in the North of Algeria, Horticulture, Prof. Alejandro Isabel Luna Maldonado (Ed.). InTech. ISBN: 978-953- 51-0252- 6.

Bettahar N., Ali Benamara A., Kettab A.and Douaoui A. (2009), Risk of nitrate pollution in semi- arid areas. If Valley Western Middle Cheliff (in French), Rev Sci Water., 22(1), 69-78.

Bierkens M.E.P. and Burrough P.A. (1993), The indicator approach to categorical data. I. Theory., J. Soil Sci , 44, 361-68.

Boulaine J.L.G. (1957), Soil Survey Plains Cheliff. PhD thesis (in French), University of Algiers, Algeria.p. 565.

Chelloufi H. and Jacquin F. (2000), Interactions water nitrates. Comparative study of nitrate leaching in four soil types, JEEC, 290-296.

CORPEN. (1988), (1999) and (2001), CORPEN standards for estimating nitrogen produced on the farm (in French). PMPOA Circular N 5010 of 15 May 2003.

Daoud Y.(1993), Contribution to the study of soil plains Chéliff. The phenomenon of salinisation affect the physical properties of clay soils (in French). Thesis Doct status, INA Algiers. p. 233.

Dash J.P., Sarangi A. and Singh D.K. (2010), Spatial variability of groundwater depth and quality parameters in the national capital territory of Delhi, Environ Manage, 45, 640-650.

Delhomme J.P. (1978), Kriging in the hydrosciences, Adv Water Resour, 1, 251-266.

Derdour H. (1981), Contribution to the study of the influence of exchangeable sodium on the behavior of the soil compaction (in French). Magister thesis INA Algiers. p. 46.

Doltra J.and Muñoz, P. (2010), Simulation of nitrogen leaching from a fertigated crop rotation in a Mediterranean climate using the EU-Rotate N and hydrus-2D models, Agricultural Water Management, 97(2), 277-285.

Douaoui A.(2005), Spatial variability of salinity and its relation with some soil characteristics of the plain of Lower Cheliff. Contribution of geostatistics and remote sensing (in French). Thesis Doct status, INA Algiers. p. 233.

Douaoui A., Herve N. and Walter C.H. (2006), Detecting salinity hazards Within a semi- arid context by moyen de combining soil and remote -sensing data, Geoderma, 134, 217--230.

Fabre J., Brunel L., Rucheton G., Mailhol J.C., Ruelle P. and Le Grusse P.(2013), A simulation tool for water resource management planning in the context of a participatory approach, Science \& Territories Waters, (in French). 11.

Firestone M.K. (1982), Biological denitrification . In: Nitrogen in agricultural soils.

Goovaerts P., AvRuskin G., Meliker J., Slotnick M., Jacquez G. and Nriagu J. (2005), Geostatistical modeling of the spatial variability of arsenic in groundwater of southeast Michigan, Water Resour Res, 41, 1-19.

Haddaj D.(1970), Influence of cultivation methods on the structural degradation of soils irrigated perimeters of the High-Cheliff. (in French), Thesis INA Algiers. p.86.

Hayenes R.J. (1986b), Uptake and assimilation of mineral nitrogen by plants. In: Mineral nitrogen in the plant soil system. Physiological ecology. In Kozlowsky T T (Ed.) Madison, Wisconsin, USA. pp. 303--378. 
Henault C. and Albacore J.C.(1995), Quantification of denitrification and emissions of nitrous oxide ( $\left.\mathrm{N}_{2} \mathrm{O}\right)$ from soils (in French), Agronomy, 15, 321-355.

Kettab A.(2005), Water for Sustainable Development (SD). An International Publication of Engineering Sciences. (in French), Algerian J. Technol., ISSN 1111- 357x. pp. 521--524.

Lee J.J., Liu C.W., Jang C.S. and Liang C.P. (2008), Zonal management of multi-purpose use of water from arsenicaffected aquifers by using a multi-variable indicator kriging approach, J Hydrol, 359, 260-73.

Liu C.W., Jang C.S. and Liao C.M. (2004), Evaluation of arsenic contamination potential using indicator kriging in the Yun-Lin aquifer (Taiwan), Sci Total Environ, 321, 173-88.

Machet J.M., Stone D., Appeal S. and Remy J.C. (1987), Meaning the real duty cycle and consequently for nitrogen fertilization of cultures (in French), CR Acad. Agric., France, 3, 39- 55.

Mailhol J.C., Ruelle P., Dejean C. and Rosique P.(2011), The subsurface drip: an innovative solution to irrigate under restrictive conditions for water, Water and Land Sciences (in French), 11.

Mario C.O., Juan A.L.E., Victor R.G., Eulogio P.I. and Lucía C.R. (2014), Categorical Indicator Kriging for assessing the risk of groundwater nitrate pollution: The case of Vega de Granada aquifer (SE Spain), Journal of Science of the Total Environment, 470-471, 229-239.

Martin C. (2003), Hydrological and hydrochemical mechanisms involved in seasonal variations in nitrate levels in agricultural watersheds. Experimental approach. (in French) PhD Thesis, School, of Reindeer, France. p. 269.

Mattauer M. (1958), Geological Survey of Eastern Ouarsenis (Algeria). (in French) Es thesis, University of Besançon, French. p.343.

Mendes M.P. and Ribeiro L. (2010), Nitrate probability mapping in the northern aquifer alluvial system of the river Tagus (Portugal) using disjunctive kriging, Sci Total Environ, 408, 1021-34

ONID. (2012), Agency of the National Office Irigation and Drainage. Plan of the National Agricultural land cadastre agency, Algeria. (in French)

Perronon A. (1957), Geological Survey subtidal Neogene basins of the North West Algeria (in French). PhD thesis, University of Algiers, Algeria. p.115.

Rodier G.(1996), Analysis of water, natural water, wastewater, seawater. In Dunod 8 (ed.) (in French) Paris, France. p.1365.

Rrmrnieras G. (1980), Hydrology Engineering. In Eyrolles (ed.) 2nd edition (in French) Paris, France. p. 455.

SCET AGRI. (1984a), Hydrology - Hydrogeology and resource balance. Study of the redevelopment and extension of the scope of the average Cheliff. (in French) Rap A1.1.2. Pub. Ministry of Water Resources, Algeria. p. 72.

SCET AGRI. (1984b), Assessment of soil resources. Study of the redevelopment and extension of the scope of the average Cheliff. (in French), Rap A1.2.1. Pub. Ministry of Water Resource Algeria.p.35.

Smith M.S. and Tiedge J.M. (1979), Phases of denitrification following oxygen depletion in soil, Soil Biol Biochem., 11, 261-267.

Stevenson F.J. (2001), Am Soc Agron. In Madison (ed.) Wisconsin, USA. pp. 289--318.

Stigter T.Y., Ribeiro L. and Dill A.C. (2006), Evaluation of an intrinsic and a specific vulnerability assessment method in comparison with groundwater salinisation and nitrate contamination levels in two agricultural regions in the south of Portugal, Hydrogeol J, 14, 79-99.

Tremblay N., Scharpf H.C., Weier U., Laurence H and Owen J. (2001), Board of Nitrogen in Vegetable Crops, Guide for Rational Fertilization. Agriculture and Agri-Food.Canada. 70 p.

Wallis K.J., Candela L., Mateos R.M. and Tamoh K. (2011), Simulation of nitrate leaching under potato crops in a Mediterranean area. Influence of frost prevention irrigation on nitrogen transport, Agricultural Water management, 98, 1629-1640.

Xu P., Hou X., Zhou F., Ying N.and Zhao G. (2013), Estimation of nitrate leaching rate and loading deduced by agricultural fertilizers in the North China Plain, Journal of Environmental Quality, 33, 3173-318 